\title{
Increased xenarthran diversity of the Great American Biotic Interchange: a new genus and species of ground sloth (Mammalia, Xenarthra, Megalonychidae) from the Hemphillian (late Miocene) of Jalisco, Mexico
}

\author{
H. Gregory McDonald ${ }^{1}$ and Oscar Carranza-Castañeda ${ }^{2}$ \\ ${ }^{1}$ Bureau of Land Management, Utah State Office, 440 West 200 South, Salt Lake City, Utah USA 84101-1345〈hmcdonald@blm.gov〉 \\ ${ }^{2}$ Centro de Geociencias, Campus Juriquilla, Universidad Nacional Autónoma de México, C.P. 76230, Juriquilla, Querétaro, México \\ $\langle$ carranza@geociencias.unam.mx $\rangle$
}

\begin{abstract}
A new genus and species of megalonychid sloth, Zacatzontli tecolotlanensis $\mathrm{n}$. gen. $\mathrm{n}$. sp., is described from the late Hemphillian of Jalisco, Mexico. Comparison and analysis of the type specimen, a mandible, with other megalonychid sloths shows a closer relationship to South American taxa than those from North America or the Caribbean. This suggests that during the early stages of the Great American Biotic Interchange there were two separate dispersal events of megalonychid sloths-an earlier one represented by Pliometanastes and the later one by Zacatzontli n. gen. While the morphology of the spout of Zacatzontli more closely resembles that of Megalonyx, based on the current record, Zacatzontli does does not enter North America until after the evolution of Megalonyx from Pliometanastes. The role of the northern neotropics in South America as a staging area for South American taxa that entered North America is discussed.
\end{abstract}

\section{Introduction}

Ongoing research of the geology and paleontology of the late Tertiary basins in the central part of Mexico, between latitudes $23^{\circ} \mathrm{N}$ and $19^{\circ} \mathrm{N}$, has been pivotal to expanding our knowledge of Hemphillian and Blancan North American Land Mammal age (NALMA) faunas found to the south of the classic localities of these ages in the North American Great Plains. The faunas recovered to date have a high mammalian diversity and represent the most important late Cenozoic faunal assemblages known south of the United States border. All of the sites that have been studied and collected consist of fluvial lacustrine deposits that form part of the Trans Mexican Volcanic Belt, and contain the earliest appearances of South American immigrants that dispersed into North America during the Hemphillian and Blancan (9.0-1.6 Ma).

The ages of these fossil records have been obtained by both radiometric and paleomagnetic analyses. These have refined our knowledge of both the earliest existence of the Panamanian land bridge that was critical for the Great American Biotic Interchange (GABI) and the timing of the dispersal of taxa prior to its formation (Carranza and Miller, 1980; Miller and Carranza-Castañeda, 2001; Carranza-Castañeda and Miller, 2004; Flynn et al., 2005; Woodburne, 2010; Carranza-Castañeda et al., 2013).

During the early Blancan, the northward dispersal of South American neotropical mammals into North America was more dynamic and involved more taxa than the earlier dispersal in the Hemphillian ( 8 Ma). Evidence of this active interchange has been recorded at several localities in the San Miguel Allende Basin, in the state of Guanajuato. These important fossil sites encompass faunas from the latest Hemphillian, dated at $4.8 \mathrm{Ma}$, as well as various early Blancan localities, dated at $4.7 \mathrm{Ma}$. We note that the Hemphillian-Blancan boundary as used here (4.8-4.7 Myr; Flynn et al., 2005) is later than that of Lindsay et al. (2002) in which this boundary was defined as $4.9-5.0 \mathrm{Ma}$ based on stratigraphic sequences in Nevada. The Mexican faunas document the earliest records in North America of taxa originating in the neotropics of South America: Glyptotherium texanum Osborn, 1903 (Gillette et al., 2016), Paramylodon garbani (Montellano-Ballesteros and Carranza-Castañeda, 1981, 1986), and Neochoerus cordobae Carranza-Castañeda and Miller, 1988 (Miller and Carranza, 1998; Miller and Carranza-Castañeda, 1999; Carranza-Castañeda and Miller, 2004; Flynn et al., 2005; Carranza-Castañeda, 2016). All of these records strongly suggest that the second stage of the GABI occurred at least $1.5 \mathrm{Myr}$ earlier than had been previously accepted based on the presence of these taxa in faunas farther north in Arizona, Texas, and Florida.

Results of additional studies in other basins in central Mexico include localities in the State of Hidalgo, such as the Las Golondrinas locality, an important late Hemphillian fauna that includes Megalonyx, as well as the Zietla fauna from which several megalonychid molariforms were recovered (Carranza-Castañeda, 1991).

Studies carried out in the state of Jalisco have revealed the significance of the Tecolotlán Basin to our understanding the early stages of the GABI in Mexico. Here the stratigraphic sequence includes an important late Hemphillian fauna in the upper part of the unit, above which rest unconformably younger beds that have been assigned to the late Blancan-early Irvingtonian NALMA, and within this sequence, South American immigrants have been discovered (Kowallis et al., 2003, 2017; Carranza-Castañeda, 2016). 


\section{Materials and methods}

The specimen described here was collected and prepared with regular procedures. All the measurements are in $\mathrm{mm}$. The specimen was compared with a cast of the jaw of Megalonyx curvidens Matthew, 1924, the jaw of Pliometanastes from Rio Vírgenes, México and housed in the LACM collections, and Pliometanastes from the Siphon Canal locality, California. The photograph of the longitudinal section of the labial side of the jaw, was made with X-Ray microtomography at the Laboratorio Universitario de Microtomografía de Rayos X (LUMIR), del Centro de Geociencias, UNAM.

Initial analysis of the volcanic ash was by $\mathrm{Ar}^{39} / \mathrm{Ar}^{40}$ and yielded an age of $4.95 \pm 0.16 \mathrm{Ma}$ (Kowallis et al., 2017). A new analysis of the volcanic ash based on $\mathrm{U} / \mathrm{Pb}$ dating using laser ablation inductively coupled plasma mass spectrometry (LAICPMS) conducted in the Laboratorio de Estudios Isotópicos del Centro de Geociencias, UNAM produced an age of $4.85 \pm 0.1 \mathrm{Ma}$.

Repositories and institutional abbreviations.-Vertebrate remains were recovered from multiple localities, which are identified as Jal Teco followed by a number to indicate JaliscoTecolotlán. Institutional abbreviations include FAM $=$ Frick
Collection, American Museum of Natural History New York; LACM = Natural History Museum of Los Angeles County, Los Angeles; MACN = Museo Argentino de Ciencias Naturales 'Bernardino Rivadavia,' Buenos Aires; MPGJ = Museo de Paleontología Geociencias, Juriquilla; MPM = Museo Regional Provincial Padre M. J. Molina, Rio Gallegos; UF = Florida Museum of Natural History, Gainesville; UNAM = Universidad Nacional Autónoma de México, México City.

\section{Tecolotlán geological setting}

The Tecolotlán Basin is located $\sim 80 \mathrm{~km}$ southwest of Guadalajara (Fig. 1). The fossil-bearing sediments that accumulated in the basin occupy a $20 \times 10 \mathrm{~km}$ area, in a $\mathrm{N}$ to SE-trending depression, centered approximately at $20^{\circ} 10^{\prime} \mathrm{N}, 104^{\circ} 03^{\prime} \mathrm{W}$, which is roughly parallel to the nearby Colima rift, located $50 \mathrm{~km}$ to the east. The continental sedimentary basin is near the northeast boundary of the Jalisco Block, which is a region bounded to the north by the WNW-trending Tepic-Zacoalco rift, to the east by the NE-trending Colima rift and to the west by the northern end of the Middle America trench (Rosas-Elguera et al., 1996). Rocks in the Jalisco block are dominated by the 100-75 Ma Puerto Vallarta batholith, and large areas are covered by intermediate to

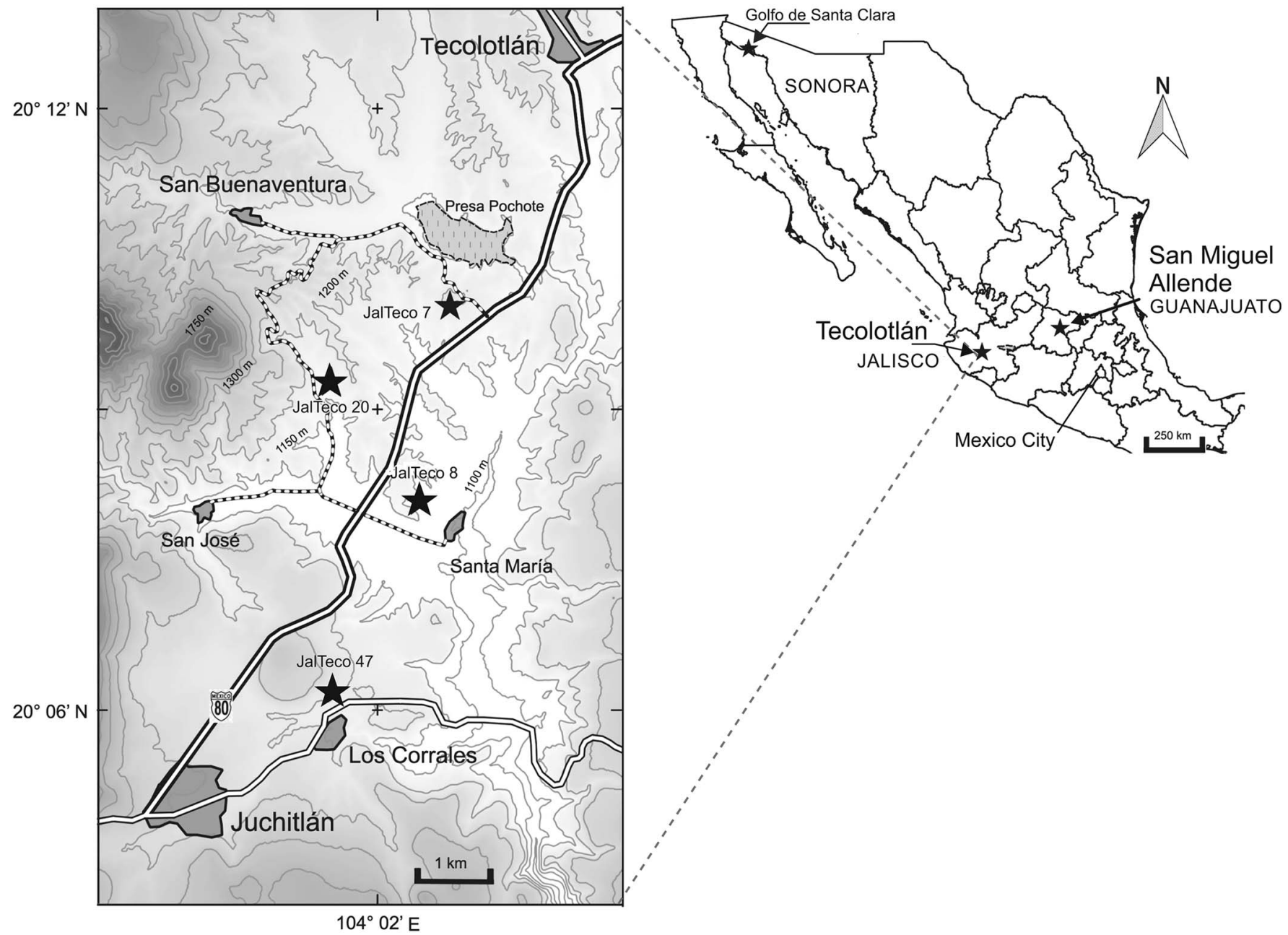

Figure 1. Map showing the location of sites in the Tecolotlán basin, Jalisco, Mexico cited in the text. The largest star is the type locality for Zacatzontli tecolotlanensis $\mathrm{n}$. gen. $\mathrm{n}$. sp. 
mafic volcanic rocks related to the Trans Mexican volcanic belt are 6-3 Ma old in the area near Tecolotlán (Rosas-Elguera et al., 1996; Gómez-Tuena et al., 2007). The origin of the Tecolotlán Basin has not been studied, but we note that on both sides of the elongated depression there exist several conspicuous NEtrending lineaments that suggest the existence of a late MiocenePliocene graben in the area. Extensive outcrops of Pliocene mafic lavas south of the town of Tecolotlán (Paizanni-Herrera et al., 1999) suggest that drainage in the graben may have been blocked periodically by volcanic products.

The basin is delimited to the east by the oldest sedimentary rocks, limestones, exposed near San José de Los Guajes, and to the west by a series of interbedded late Cretaceous volcanic and sedimentary rocks informally called the Juchitlán beds (Kowallis et al., 2017).

Before 1997, there was no previous work related to the biostratigraphy of the Tecolotlán Basin. The first contributions were made by B. Kowallis of Brigham Young University (Kowallis et al., 1998, 2003). Kowallis et al. (2017) recently finished the most complete study of the area.

Stratigraphy.-The Tecolotlán Basin is filled with fluviallacustrine sediments, consisting of poorly consolidated muds, clays, and sandstones that contain an abundance of North American mammalian faunas, many of which include South American immigrants, along with reptiles and fishes. Interbedded with these sediments are several important volcanic ashes that can be radiometrically dated. For the time being, this interesting late Hemphillian sequence has been informally called the San José beds (Kowallis et al., 2017).

Resting at the upper part of the sequence, above an erosional unconformity, is a more recent unit composed of sands, gravel, and sandy mudstones. This part of the section is named the San Buenaventura beds (Kowallis et al., 2003, 2017) and the age is assigned to the latest Blancan-Irvingtonian. In the southeast of the basin near the town of Juchitlan, another late Blancan deposit, Jal Teco 47 Los Pitahayos, has been described and contains the remains of two South American immigrant taxa: Glyptotherium cylindricum Brown, 1912 and Neochoerus occidentalis Carranza Castañeda, 2016.

Because the distance between the late Hemphillian localities in which the fossil materials were collected is so great within the basin, for the purpose of this work, it was decided to consider two areas of major importance, taking into consideration that one third of the sequence is referred to the late Blancan (Fig. 2).

The Santa María area.- This locality is named for its location near a small ranch called Santa María, at the southeast portion of the basin $\left(20^{\circ} 07^{\prime} 24^{\prime \prime} \mathrm{N} ; 104^{\circ} 03^{\prime} 39^{\prime \prime} \mathrm{W}\right)$. This general area lies along a complex system of deep arroyos, and the exact fossil site corresponds to the major canyon, situated just south of the ranch. Here, the thickness of the sediments measures $28-30 \mathrm{~m}$. At the base of the section are layers of gravel covered by clays with sands of different sizes. This alternation of clays with sands is only interrupted by a horizon of compacted and characteristically reddish clay. Above this clay is a paleo-channel composed of fine-grained sand from which several rodent molars, along with the two megalonychid molariforms referred to the new taxon described in this work, were found. At the top of the fossiliferous paleo-channel, there are several layers of clays and gravel, and the sequence ends with a series of lacustrine sediments and layers of clay that are 2-6 m thick and show evidence of soil development and roots. Above the whole section there are sandy outcrops cemented by carbonates in which freshwater gastropods are common. It is interesting to note that the cemented sands occur along the entire basin, separating the lower fluvial-lacustrine sediments of the Santa María sequence from the higher San José beds.

The San José beds area.-This sequence is well represented at the locality called Jal Teco $20 \mathrm{La}$ Hacienda $\left(20^{\circ} 08^{\prime} 56^{\prime \prime} \mathrm{N}\right.$; $\left.104^{\circ} 04^{\prime} 56^{\prime \prime} \mathrm{W}\right)$. Access to the locality is by Highway 81 from Tecolotlán. The site is near the ruins of an old mansion called La Hacienda, from which the locality name is derived.

The thickness of this section, measured from the top of the consolidated carbonate sands, is $20-30 \mathrm{~m}$. It consists of layers of clays and sands at the base, and is covered by clayish sediments. It is from this sequence that the jaw of the new megalonychid taxon described in this paper was collected. Stratigraphically, it was found about one meter below a layer of volcanic ash and $12 \mathrm{~m}$ above the base of the unit. The tuff from the San José beds produced some grains of sanidine that were dated by ${ }^{40} \mathrm{Ar} /{ }^{39} \mathrm{Ar}$ and gave an age of $4.95 \pm 0.02 \mathrm{Ma}$ (Kowallis et al., 2017). More recently another analysis of the same layer from a different site was analyzed by the $\mathrm{U} / \mathrm{Pb}$ method using zircons, which produced a date of $4.85 \pm 0.1 \mathrm{Ma}$ for the ash (LA-ICPMS), by Laboratorio de Estudios Isotópicos, Centro de Geociencias, UNAM. The results of these two radiometric assessments are consistent and correspond with the estimated biostratigraphic ages based on the mammalian species present in the San José beds.

Resting on the upper part of the sequence, above an erosional unconformity, there is a more recent unit composed of sands, gravel, and sandy claystones. This part of the section has been named "The San Buenaventura beds." These sediments are thought to be Blancan in age, and their thickness varies at different sites. The most complete section is at the Jal Teco 7 Las Gravas locality, with at least $30 \mathrm{~m}$ of exposed sediments. The basal bed is irregular and its lower contact with the San José beds is not exposed. In general, the lithology of the sequence consists of layers of sandy clay, paleo-channels with gravels, some sandy layers of variable thicknesses, and other strata with sands and many paleo-channels.

Locality Jal Teco 47 Los Pitahayos.- - In the southeastern part of the basin, near the town of Juchitlán, another late Blancan deposit was described only $300 \mathrm{~m}$ away from the Los Corrales ranch, the Jal Teco 47 Los Pitahayos locality $\left(20^{\circ} 05^{\prime} 02^{\prime \prime} \mathrm{N} ; 104^{\circ}\right.$ $05^{\prime} 38^{\prime \prime} \mathrm{W}$ ).

The thickness of the sediments at the site is $\sim 20 \mathrm{~m}$. The fauna includes two South American immigrants, Neochoerus occidentalis and Glyptotherium cylindricum, along with Equus simplicidens Cope, 1892, aff. Stockoceros, Platygonus sp., osteoderms and teeth of crocodiles, parts of turtle carapace, and fish remains (operculae). The late Blancan age assigned to this unit was estimated through the analysis of a pyroclastic fall tuff, discovered within the sediments, which was dated using ${ }^{40} \mathrm{Ar} /{ }^{39} \mathrm{Ar}$ and gave a date of $2.62 \pm 0.03 \mathrm{Ma}$ (Kowallis et al., 2017). 


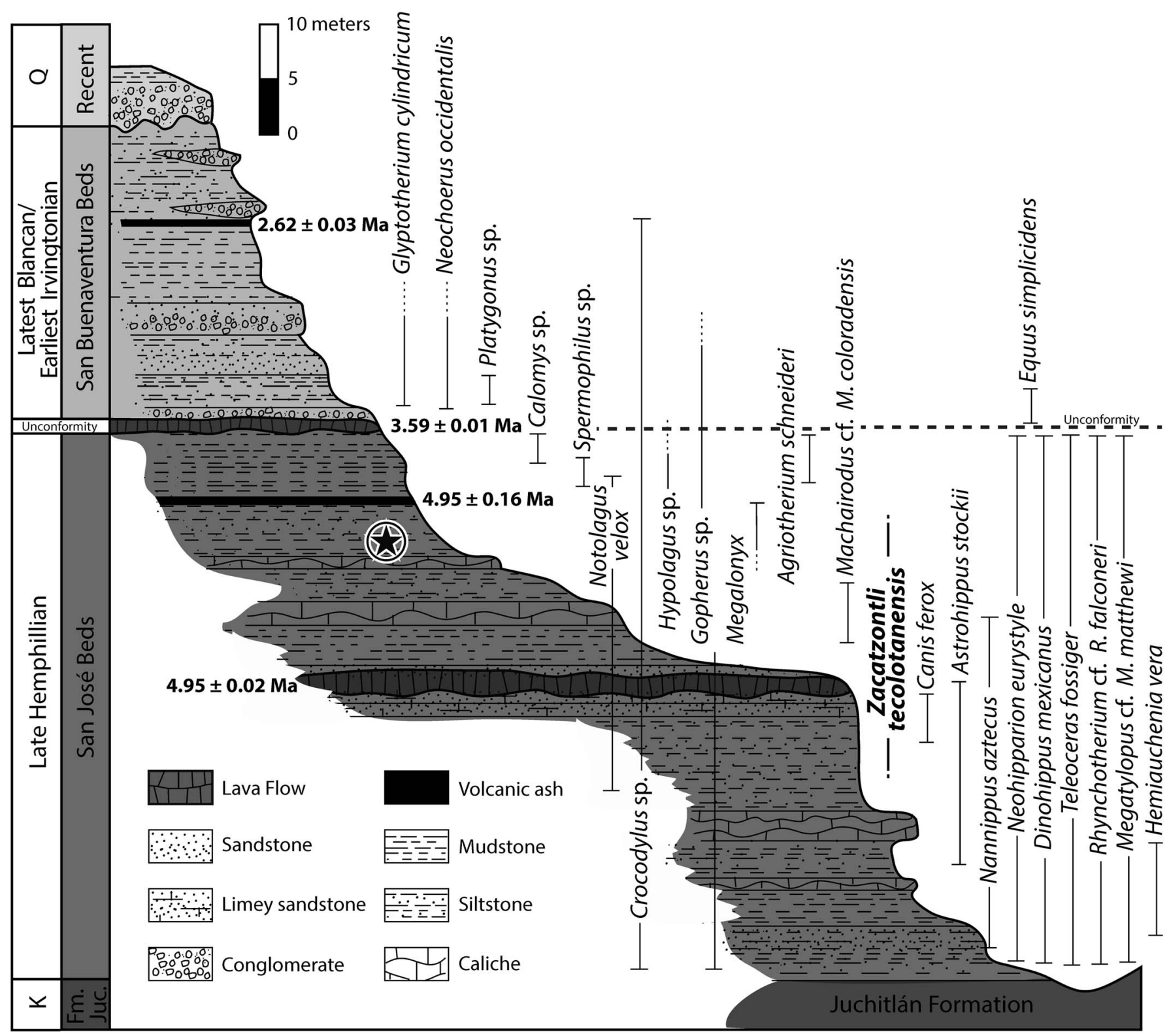

Figure 2. Composite stratigraphic section for the latest Hemphillian to latest Blancan/earliest Irvingtonian in the Tecolotlán Basin and the stratigraphic occurrences of the fauna. The star indicates the level at which the type of Zacatzontli tecolotlanensis $\mathrm{n}$. gen. n. sp. (MPG 1312G) was collected.

At the bottom of the stratigraphic sequence the sediments that correspond to this part of the section at Santa María are buried by alluvium. The San José beds at this locality are represented by paleosols, clay, and sands that are $\sim 3 \mathrm{~m}$ thick. These sediments represent a marsh environment, as indicated by the preservation of tubers and other plant remains. These sediments are covered by layers of consolidated sands that contain gastropods. The mammalian remains were recovered from the top of this sequence and include Megalonyx sp. Jefferson, 1799; Dinohippus mexicanus Lance, 1950; Neohipparion eurystyle Matthew, 1909; Teleoceras fossiger (Cope, 1878); Rhynchotherium cf. R. falconeri Osborn, 1923; and Hemiauchenia vera Matthew, 1909.

Age and associated fauna.- The associated Hemphillian fauna of the Tecolotlán basin is represented in two main localities. In the lower part of the stratigraphic sequence is the Santa María fauna, considered to be late Hemphillian (Hh3), based on the abundance of the equids Nannippus aztecus Mooser, 1968; Neohipparion eurystyle (Cope, 1893); and Dinohippus mexicanus Lance, 1950; along with limited remains of Astrohippus stockii Lance, 1950; Teleoceras fossiger (Cope, 1878); and the carnivores Borophagus secundus Matthew and Cook, 1909; Canis ferox Miller and Carranza-Castañeda, 1998; and Agriotherium schneideri Sellards, 1916 (Carranza-Castañeda et al., 2013). A list of the mammalian fauna is provided in Table 2. Above the Santa María fauna is the $\mathrm{La}$ Hacienda fauna, which is also considered to be $\mathrm{Hh} 3$ in age because the only difference between the two faunas is the absence of Nannippus aztecus in the latter. A volcanic ash interbedded with the fauna was dated using the ${ }^{40} \mathrm{Ar} /{ }^{39} \mathrm{Ar}$ method and yielded an age of $4.95 \pm 0.02 \mathrm{Ma}$ (Kowallis et al., 2017). A new analysis in the same volcanic ash, carried out by the Laboratorio de Estudios 
Table 1. Measurements of the mandibles of Zacatzontli tecolotlanensis n. gen. n. sp. (MPG 1312G), Pliometanastes protistus Hirschfeld and Webb, 1968 (UCMP 97371), and Megalonyx curvidens Matthew, 1924 (FAM 77800); measurements in mm; *approximate length (posterior margin broken); - data not available.

\begin{tabular}{|c|c|c|c|}
\hline Measurement & $\begin{array}{l}\text { Zacatzontli } \\
\text { tecolotlanensis } \\
\text { n. gen. n. sp. } \\
\text { MPG } 1312 \mathrm{G}\end{array}$ & $\begin{array}{c}\text { Pliometanastes } \\
\text { protistus } \\
\text { UCMP } 97371\end{array}$ & $\begin{array}{c}\text { Megalonyx } \\
\text { curvidens } \\
\text { FAM } 77800\end{array}$ \\
\hline Length from tip of symphysis to posterior margin of angular process & $121.6^{*}$ & 226 & - \\
\hline Length from tip of symphysis to posterior margin of condyle & 120.3 & 225 & - \\
\hline Length from anterior margin of alveolus of caniniform to posterior margin of alveolus of $\mathrm{m} 3$ & 50.0 & 94.3 & 85.9 \\
\hline Length from anterior margin of spout to anterior margin of caniniform alveolus & 15.0 & 37.6 & 18.0 \\
\hline Width across caniniforms & 34.8 & 58.1 & \\
\hline Width across buccinator fossae & 28.0 & 45.7 & \\
\hline Length of mandibular symphysis & 30.8 & 47.5 & 54.1 \\
\hline Width of spout at midpoint & 15.9 & & \\
\hline Height of mandibular symphysis & 24.7 & 49.8 & 46.7 \\
\hline Dorsoventral depth of horizontal ramus at $\mathrm{m} 1$ & 28.7 & 58.7 & 52.1 \\
\hline Dorsoventral depth of horizontal ramus at $\mathrm{m} 3$ & 25.1 & 56.7 & - \\
\hline Length of diastema & 9.1 & 25.2 & 21.7 \\
\hline Mediolateral width of diastema & 7.1 & 10.0 & 8.8 \\
\hline Molariform alveolar length & 30.4 & 54.6 & 48.7 \\
\hline Dorsoventral depth of angular process at base & 17.8 & 36.5 & - \\
\hline Labiolingual width of caniniform & 6.4 & 10.8 & 10.8 \\
\hline Mesiodistal length of caniniform & 6.9 & 12.0 & 19.3 \\
\hline Mesiodistal length of alveolus of m1 & 7.5 & 14.4 & \\
\hline Labiolingual width of alveolus of $\mathrm{m} 1$ & 9.1 & 20.8 & \\
\hline Mesiodistal length of alveolus of m2 & 6.9 & 14.9 & \\
\hline Labiolingual width of alveolus of $\mathrm{m} 2$ & 9.6 & 21.8 & \\
\hline Mesiodistal length of alveolus of m3 & 11.1 & 19.1 & \\
\hline Labiolingual width of alveolus of $\mathrm{m} 3$ & 8.4 & 18.8 & \\
\hline \multirow[t]{2}{*}{ Lower right first molariform (Jal-Teco 8) } & Mesiodistal length 7.9 & & \\
\hline & Labiolingual width 9.8 & & \\
\hline \multirow[t]{2}{*}{ Lower left third molariform (Jal-Teco 8) } & Mesiodistal length 8.9 & & \\
\hline & Labiolingual width 11.05 & & \\
\hline
\end{tabular}

Table 2. Faunal list of the late Hemphillian deposits of Tecolotlán, Jalisco, Mexico.

\begin{tabular}{|c|c|c|}
\hline & $\begin{array}{l}\text { Santa María } \\
\text { Jalteco } 8\end{array}$ & $\begin{array}{l}\text { La Hacienda } \\
\text { JalTeco } 20\end{array}$ \\
\hline \multicolumn{3}{|l|}{ Class Reptilia } \\
\hline Amphibia Indet. & $\mathrm{X}$ & \\
\hline \multicolumn{3}{|l|}{ Order Squamata indet. } \\
\hline Suborder Lacertilia indet. & $\mathrm{X}$ & \\
\hline Suborder Serpentes indet. & $\mathrm{X}$ & $\mathrm{X}$ \\
\hline \multicolumn{3}{|l|}{ Order Crocodilia } \\
\hline Crocodylus sp. & $\mathrm{X}$ & $\mathrm{X}$ \\
\hline \multicolumn{3}{|l|}{ Class Mammalia } \\
\hline \multicolumn{3}{|l|}{ Order Xenarthra } \\
\hline Megalonyx sp. & & $\mathrm{X}$ \\
\hline $\begin{array}{l}\text { Zacatzontli tecolotlanensis n. gen. n. sp. } \\
\text { Order Lagomorpha }\end{array}$ & Two teeth & Jaw \\
\hline Notolagus sp. & $\mathrm{X}$ & \\
\hline \multicolumn{3}{|l|}{ Order Rodentia } \\
\hline Sigmodon sp. & $\mathrm{X}$ & $\mathrm{X}$ \\
\hline Calomys & & $\mathrm{X}$ \\
\hline \multicolumn{3}{|l|}{ Spermophilus } \\
\hline \multicolumn{3}{|l|}{ Order Carnivora } \\
\hline Agriotherium schneideri Sellards, 1916 & $\mathrm{X}$ & \\
\hline $\begin{array}{l}\text { Canis ferox Miller and Carranza- } \\
\text { Castañeda. } 1998\end{array}$ & & $\mathrm{X}$ \\
\hline $\begin{array}{l}\text { Borophagus secundus Matthew and } \\
\text { Cook, } 1909\end{array}$ & $\mathrm{X}$ & $\mathrm{X}$ \\
\hline $\begin{array}{l}\text { Machairodus } \text { cf. M. coloradensis Cook, } \\
1922\end{array}$ & $\mathrm{X}$ & \\
\hline \multicolumn{3}{|l|}{ Order Proboscidea } \\
\hline $\begin{array}{l}\text { Rhynchotherium cf. } R \text {. falconeri } \\
\text { Osborn, } 1923\end{array}$ & $\mathrm{X}$ & $\mathrm{X}$ \\
\hline \multicolumn{3}{|l|}{ Order Perissodactyla } \\
\hline Nannippus aztecus Mooser, 1968 & $\mathrm{X}$ & \\
\hline Neohipparion eurystyle (Cope, 1893) & $\mathrm{X}$ & $\mathrm{X}$ \\
\hline Astrohippus stockii Lance, 1950 & $\mathrm{X}$ & $?$ \\
\hline Dinohippus mexicanus Lance, 1950 & $\mathrm{X}$ & $\dot{X}$ \\
\hline Teleoceras fossiger (Cope, 1878) & $\mathrm{X}$ & $\mathrm{X}$ \\
\hline \multicolumn{3}{|l|}{ Order Artiodactyla } \\
\hline $\begin{array}{l}\text { Hemiauchenia vera Matthew and } \\
\text { Osborn, } 1909\end{array}$ & $X$ & $\mathrm{X}$ \\
\hline Megatylopus matthewi Webb, 1965 & $\mathrm{X}$ & $\mathrm{X}$ \\
\hline Hexobelomeryx frickii Furlong, 1941 & $\mathrm{X}$ & $\mathrm{X}$ \\
\hline Catagonus brachydontus Wright, 1983 & $\mathrm{X}$ & $\mathrm{X}$ \\
\hline
\end{tabular}

Isotópicos del Centro de Geociencias, UNAM, (LA-ICPMS), based on $\mathrm{U}-\mathrm{Pb}$ in zircons and using laser ablation gave an age of $4.85 \pm 0.1$ Ma. Based on the fauna, the Santa María fauna correlates with the Rhino layer of Rancho El Ocote and the lower layer of the Coecillos locality in the state of Guanajuato. Both faunas also include Megalonyx (Table 2).

\section{Systematic paleontology}

Order Xenarthra Cope, 1889

Suborder Pilosa Flower, 1883

Family Megalonychidae Gervais, 1855

Genus Zacatzontli new genus

Remarks.-Because Zacatzontli n. gen. is a monospecific genus, all information related to it is given below under the new species.

\section{Zacatzontli tecolotlanensis $\mathrm{n}$. gen. n. sp.} Figure 3 Table 1

Holotype--MPGJ 3126, partial mandible with complete left ramus missing dorsal portion of the coronoid process, posterior margin of the angular process and anterior portion of the right horizontal ramus broken at the midline of the alveolus of the third molariform. Both caniniforms are present, but the molariforms are missing.

Referred specimens.-MPGJ 1381, lower left third molariform and MPGJ 3534, lower right first molariform; both specimens from Jal-Teco 8 Santa María Locality. 


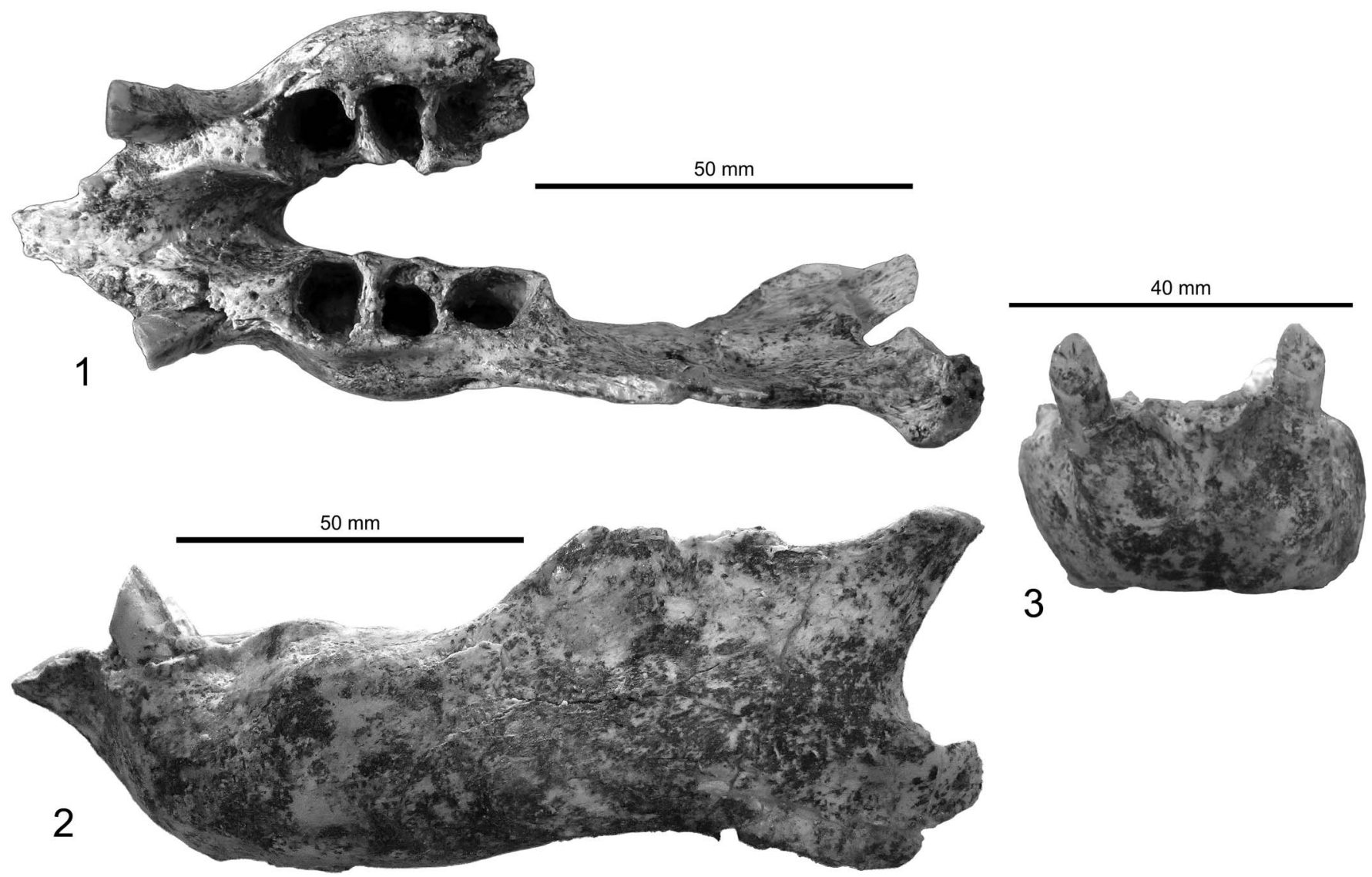

Figure 3. Mandible of Zacatzontli tecolotlanensis n. gen. n. sp. (MPG 1312G): (1) dorsal, (2) left lateral, and (3) anterior views.

Etymology.-Zacatzontli (Nahuatl) named for the Aztec god of travelers, in reference to the sloth dispersing from South to North America. Specific epithet tecolotlanensis named for Tecolotlán ("place of owls," Nahuatl) the town and municipality in Jalisco, Mexico near where the specimen was found.

Type locality._-Jal Teco 20 La Hacienda, Tecolotlán, Jalisco, Mexico 208.44'69"N; 104²'37.39"W, elevation $1177 \mathrm{~m}$.

Age.-Late Miocene, Hemphillian, Hh3 and older than the radiometric date of ash at $4.89 \mathrm{Ma}$ and associated fauna; San José beds.

Diagnosis. - Small ground sloth similar in size to the smaller Late Pleistocene megalonychids Acratocnus and Neocnus, from the Caribbean and Eucholoeops and Proschismotherium from the late Miocene of Argentina; lower caniniform triangular in cross section with prominent carina on distal margin of the tooth; predental spout triangular in dorsal view quickly narrowing anteriorly; keel on mandibular symphysis restricted to dorsal half, with small fossa between keel and caniniform in which is located the mental foramen; horizontal ramus below molariforms uniform in anterodorsal width and lacks prominently convex ventral margin; prominent lateral bulge of horizontal ramus opposite first and second molariforms, prominent groove at base of condylar process and anterodorsal margin of angular process.
Description.-The specimen consists of a complete left mandible missing only the dorsal portion of the coronoid process, posterior margin of the angular process and the posterior portion of the right horizontal ramus broken at the midline of the alveolar of the third molariform. The caniniforms are present, but the molariforms are missing (Fig. 3). There is some slight breakage along the margins of the predental spout, but this damage does not preclude being able to determine the morphology of the spout.

The lower caniniform has a mesial tilt so that its long axis is at $\sim 45^{\circ}$ to the horizontal ramus. It is triangular in cross section with the apex of the triangle on the distal side. The long axis of the tooth slopes slightly anterior so that the occlusal surface has formed at an acute angle to the axis of the tooth, resulting in it being at a right angle to the plane of the tooth row. The occlusal surface of the caniniform faces mesially and is worn at $\sim 45^{\circ}$ angle to the axis of the tooth. The mesiolingual and mesiolabial corners of the caniniform are rounded. The distal apex of the tooth has a distinct carina that extends the length of the tooth. The caniniform is slightly displaced labially so its lingual margin is in the same plane as the midline of the molariform series.

The spout is triangular and quickly narrows from its base just anterior to the caniniforms to a point. The triangular shape of the predental spout is more similar to Megalonyx than Pliometanastes. In Zacatzontli n. gen., the anterior margin of the spout is relatively narrower for its width than in Megalonyx. In Pliometanastes, the predental spout is longer, and retains essentially the same width its 

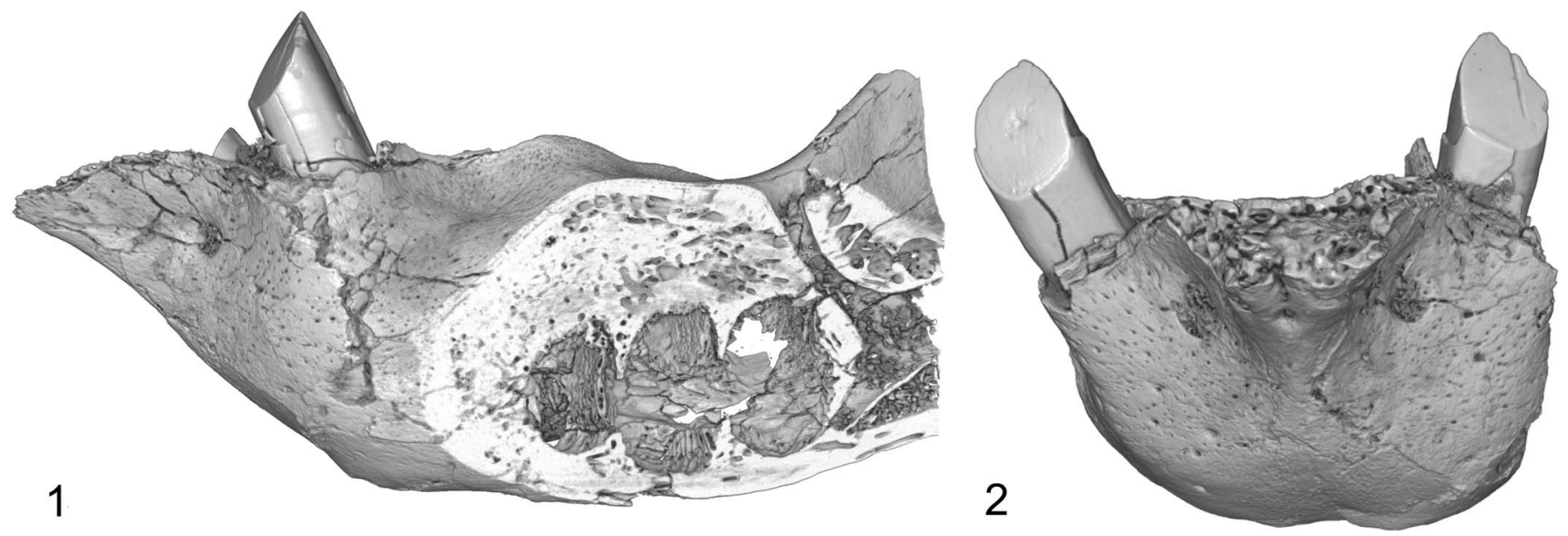

Figure 4. CT scan of mandible of Zacatzontli tecolotlanensis n. gen. n. sp. (MPG 1312G): (1) lateral view through sagittal place of alveoli and showing posterior mandibular canal, and (2) anterior view.

entire length. In Zacatzontli n. gen., the length of the spout is $30 \%$ of the length of the anterior of the caniniform to the distal margin of the m3. This value is $18-20 \%$ in Megalonyx curvidens Matthew, 1924 (FAM 77800 from Pliohippus Draw, Nebraska) and 40\% in Pliometanastes protistis Hirschfeld and Webb, 1968 (UCMP 97371 from Siphon Canal, California). The dorsal surface of the spout is concave and continuous with the concave surface of the interior surface of the mandibular symphysis. The posterior margin of the symphysis ends at about the midpoint of the diastema and anterior to the first lower molariform. On the anterior midline of the spout there is a well-defined keel on the dorsal half; ventral to the keel the surface is flat. There is a shallow concavity on either side of the keel in which is located the mental foramen (Fig. 4).

The spout of the mandible in Zacatzontli $\mathrm{n}$. gen. is perhaps one of its most distinctive features when compared to coeval megalonychid sloths in both North and South America. Its short triangular shape is reminiscent of Megalonyx, often considered the most derived spout morphology in the family. In the other Hemphillian and older megalonychids, the predental spout of the mandible is elongated and exceeds the length of the diastema (Fig. 5).

The diastema is relatively long, $29 \%$ of the length of the molariform series. It is relatively thick and the lateral side has the concave buccinator fossa, which extends from the posterior margin of the alveolus of the caniniform to the anterior margin of the alveolus of the first molariform.

Although the lower molariforms have been lost, the shapes of the alveoli permit a determination of their outline and size. The lower molariforms are all roughly the same size and only slightly larger than the caniniform. The horizontal ramus at the level of the molariforms is expanded laterally, a feature also seen in the middle Pleistocene genus Meizonyx (Webb and Perrigo, 1985). The ventral margin of the horizontal ramus is not strongly convex and essentially horizontal, so maintains a uniform width from the caniniform to the third molariform and does not become dorsoventrally deep as in Megalonyx and other members of the family. The outline of the alveolus of the lower first molariform is oval with the long axis perpendicular to the long axis of the tooth row. The outline of the alveolus of the second molariform is triangular with rounded vertices and one vertex on the lingual side. The outline of the alveolus of the lower third molariform is slightly ovoid with the axis from mesiolingual to distolabial.

The anterior margin of the ascending ramus has a posterior inclination. The base of the ascending ramus is at the midpoint of the third molariform so the distal half of the tooth is not visible when viewed laterally. The masseteric fossa is shallow and restricted to the coronoid process. The fossa is not subdivided into two distinct areas for the insertion of the zygomaticomandibularis and deep masseter muscles, which is present in some other megalonychids.

The posteroexternal foramen of the mandibular canal is positioned on the lateral side of the horizontal ramus opposite the mesial margin of the lower third molariform and the anterior margin and base of the coronoid process (Fig. 4). Although its position is similar to that of Pliometanastes and Megalonyx, it opens anterodorsally and not laterally, as in the other two genera.

The posterointernal foramen of the mandibular canal is below the dorsal margins of the molariform alveoli and below the midpoint of the coronoid process. It opens into a shallow fossa that extends below the notch between the coronoid and condyloid processes. There is a complimentary convexity on the lateral side of the dentary.

The long axis of the condyle is from anterolateral to posteromedial. The articular surface is horizontal and its posterior margin is rounded in dorsal view.

The posterior margin of the angular process is broken, but enough is preserved to indicate its posterior portion curves slightly medially and the ventral margin has a slight medial curvature. The ventral portion of the lateral surface has a small elongate fossa that extends from the plane at the posterior base of the coronoid process to the posterior edge of the preserved portion of the angular process just above its ventral margin. In the notch between the angular and condylar process there is a small fossa.

\section{Phylogenetic relationships}

McDonald et al. (2013) recovered three major clades within the family Megalonychidae; Caribbean (Megalocnus, Parocnus, Acratocnus, and Neocnus), North American (Pliometanastes and Megalonyx), and South American (Megistonyx and Ahytherium). 


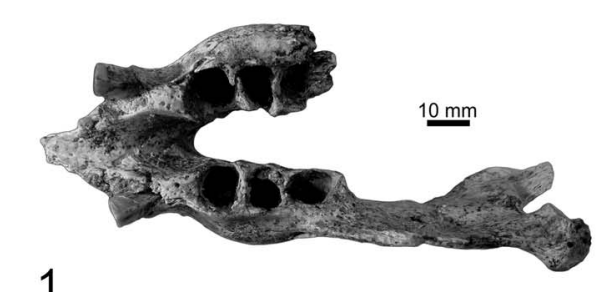

1
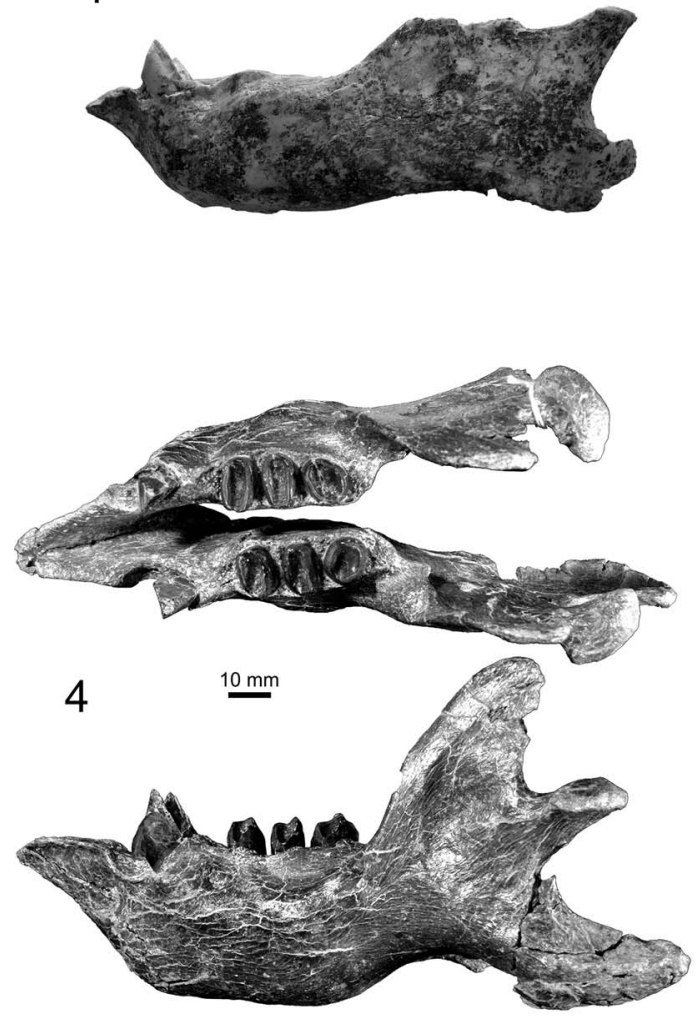
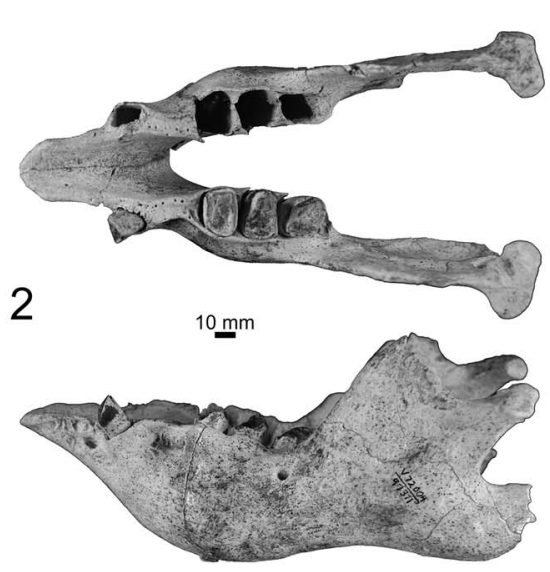

3
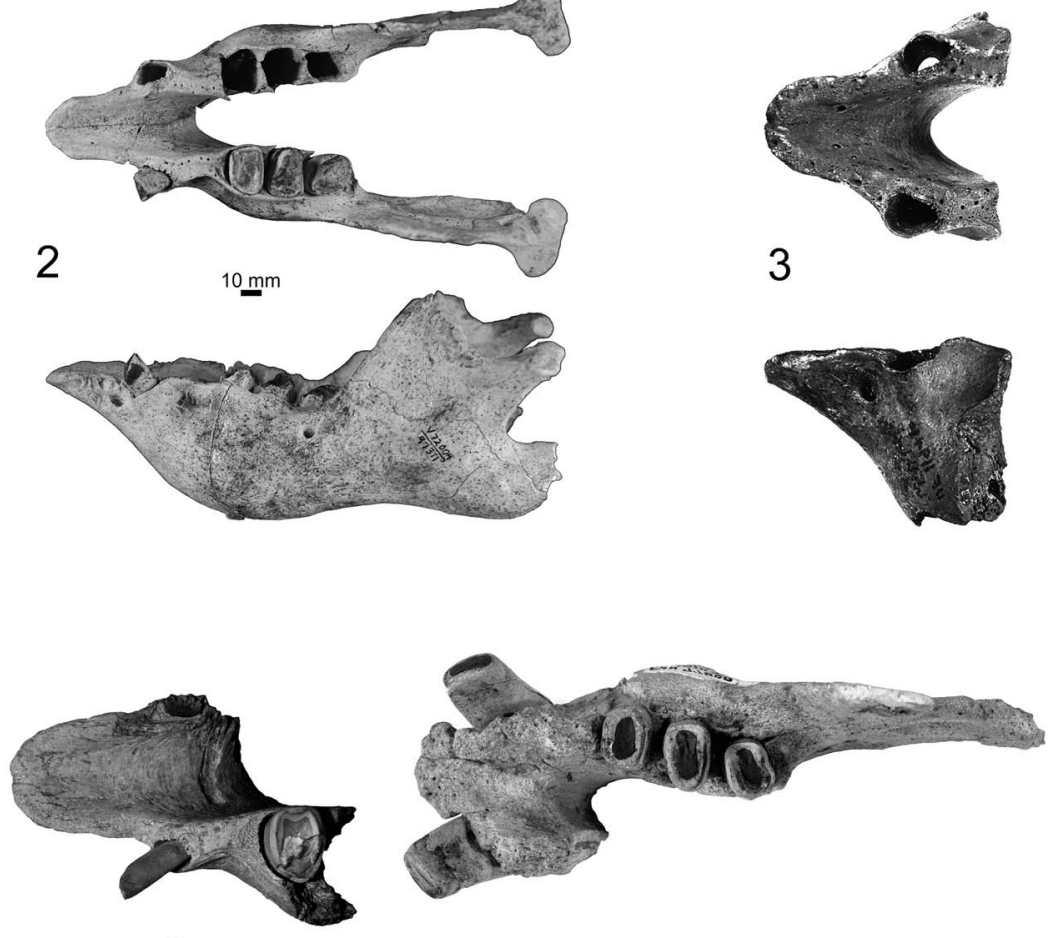

5
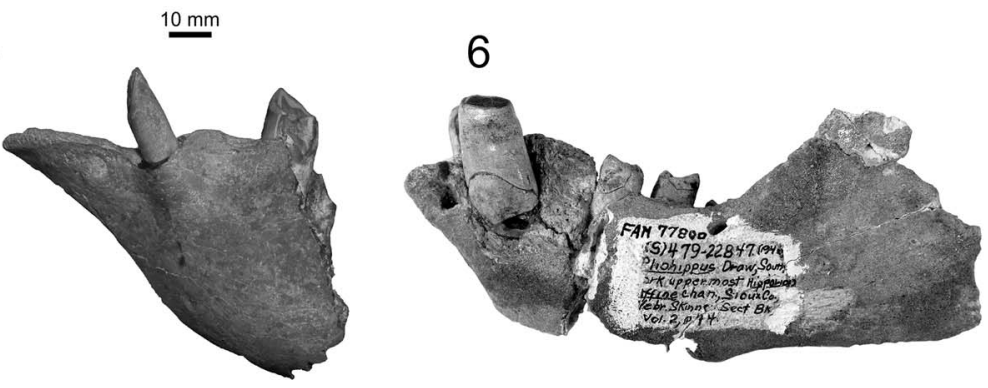

Figure 5. Comparison of anterior jaw morphology of Miocene megalonychid sloths in dorsal and lateral views: (1) Zacatzontli tecolotlanensis n. gen. n. sp. (MPG 1312G); (2) Pliometanastes protistus (UCMP 97371); (3) Pliometanastes protistus (UF 11941); (4) Eucholoeops ingens Ameghino, 1887 (MPM-PV 3401); (5) Ortotherium laticurvatum Ameghino, 1885 (MACn PV-13657); (6) Megalonyx curvidens (FAM 77800); (3) and (6) after Hirschfeld and Webb (1968); (4) after Bargo et al., 2012; (5) after Brandoni, 2010.

The question is, to which of these clades does Zacatzontli n. gen. belong? Inclusion within either the Pliometanastes-Megalonyx or Caribbean clade would suggest it is derived from the earliest dispersal into North/Central America or the Caribbean, while inclusion in the Megistonyx and Ahytherium clade would suggest perhaps a later dispersal event into North America. Based on the preliminary analysis based on the mandible, Zacatzontli $\mathrm{n}$. gen. clusters with the South American clade and not the North American or Caribbean clades.

Currently it has not been possible to link the earliest sloth taxa in North and Central America with potential ancestral forms or at least sister taxa in South America. While the mylodont Thinobadistes has been linked to Lestodon in a number of taxonomic analyses (e.g., Webb, 1989; Gaudin, 2004), Lestodon occurs considerably later than Thinobadistes. Likewise the genera Pliometanastes, Megalonyx, Meizonyx, and now Zacatzontli $\mathrm{n}$. gen. are currently only known from North America and lack a South American counterpart. Given the Hemphillian age of Pliometanastes and Zacatzontli n. gen., one would expect to find either of these genera in the Chasicoan, Huayquerian, or Montehermosan SALMAs, which cover the same span of time.
While Megalonyx first appears in the late Hemphillian, it is currently considered to have evolved in North America from Pliometanastes. A number of South American megalonychid genera are described from this time interval, including Amphiocnus, Megalonychops, and Paranabradys (McDonald and De Iuliis, 2008), as well as Pliomorphus, Ortotherium, and Mesopotamocnus from the "Conglomerado osífero" of the Ituzaingó Formation, 'Mesopotamiense' which has been considered equivalent to both the Chasicoan and Huayquerian (Brandoni, 2010, 2014). This would seem to make these taxa all potential candidates to have either participated in the GABI or at least be potential ancestors or the sister taxa to the North American forms.

Because many of these taxa are known only from the types and some are based on parts of the post-cranial skeleton, this limits any extensive or detailed comparisons with the North American megalonychids. While the skull of Pliomorphus is known, no mandibles have been referred to this genus. Given the significantly smaller size of Zacatzontli $\mathrm{n}$. gen. compared to Pliomorphus, we do not consider it likely they are the same taxon. Ortotherium, Paranabradys, and Mesopotamocnus are 


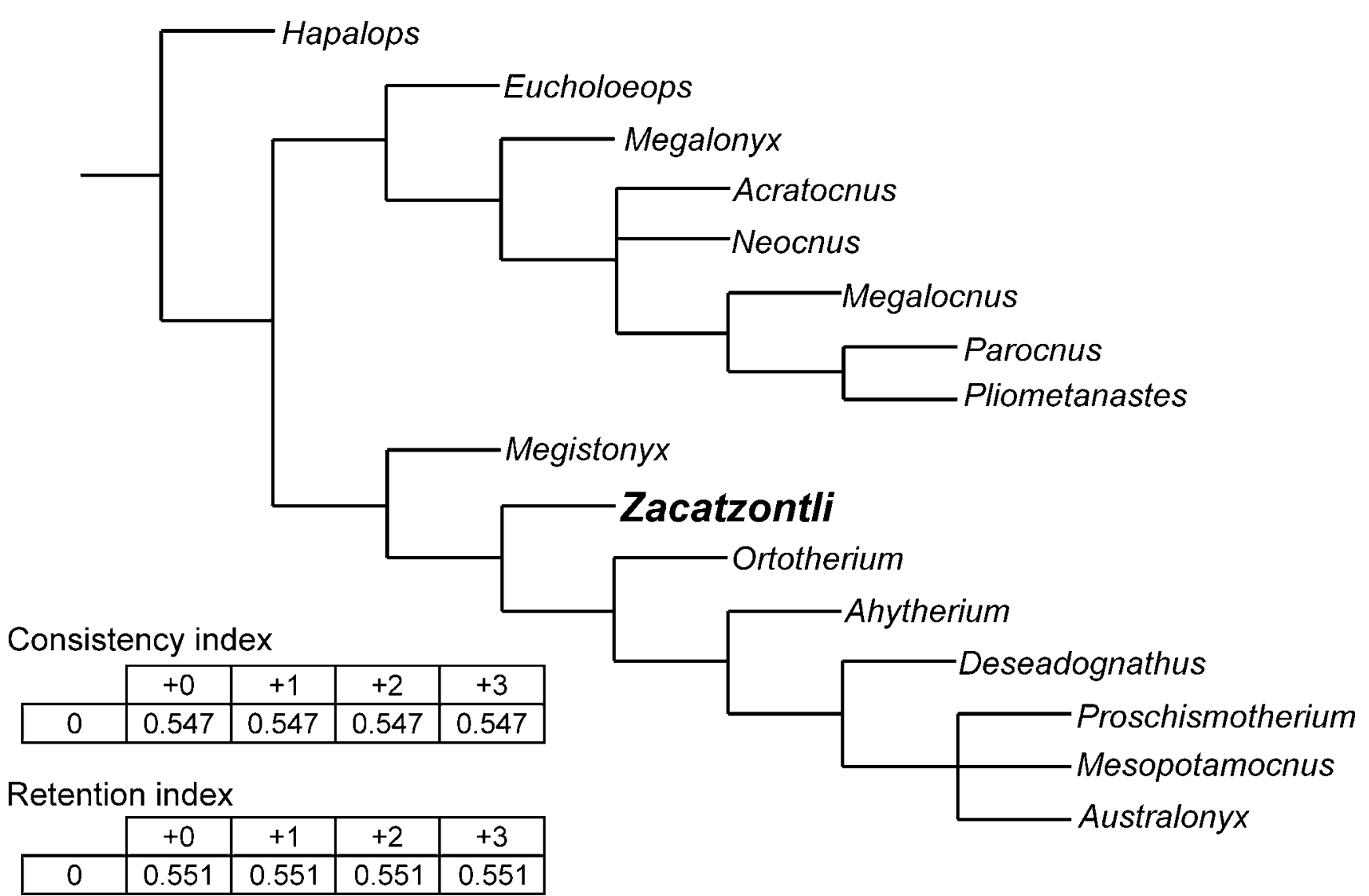

Figure 6. Strict consensus of 4 trees ( 0 taxa excluded), "Implicit enumeration" based on TNT (Tree New Technologies), Goloboff et al., 2008; RI = Retention Index, defined to be 0 for parsimony uninformative characters; CI = Consistency Index, CI $=1$ if there is no homoplasy. Characters used for analysis from Scott, 1903-1904; Kraglievich, 1923; Simpson, 1932; Matthew and Paula Couto, 1959; Hooijer, 1962; Paula Couto, 1967; McDonald, 1977; Mayo, 1980; Naples, 1982, 1987; Patterson et al., 1992; Gaudin, 1995; White and MacPhee, 2001; Carlini and Scillato-Yané, 2004; Cartelle et al., 2008; De Iuliis et al., $2009,2016$.

known from mandibles, although often incomplete, so while the first two genera are included in our analysis of the taxonomic relationships of Zacatzontli n. gen., many characters could not be scored, which further reduces the strength of any interpretations of its relationship to these taxa. Since Meizonyx from the middle Pleistocene of El Salvador is known from the mandible, it has been included in this analysis.

Despite the many megalonychid genera currently described, many are based on fragmentary remains and could not be included in this or other analyses (e.g., Gaudin, 2004; McDonald et al., 2013). Consequently, our analysis here is only intended to provide a first approximation of the possible relationship of Zacatzontli $\mathrm{n}$. gen. to the other megalonychids with which it can be compared (Fig. 6). A fuller analysis will require the recovery of better-preserved and more complete material, particularly the cranium. Given that the analysis is limited to the mandible and is therefore restricted in the number of characters available, we consider the resulting tree to provide a tentative representation of the phylogenetic relationship of Zacatzontli $\mathrm{n}$. gen. and the megalonychid taxa examined, and it should only be considered a first approximation that will require additional testing as more material becomes available.

Although this analysis does recover a North AmericanCaribbean clade and a South American clade (Fig. 6), some of the resulting relationships are quite different from those recovered by Gaudin (2004) and McDonald et al. (2013), such as the recovery of Pliometanastes as the sister taxon to Parocnus, and Megistonyx as the sister group to the other South American megalonychids and not to Ahytherium. The position of the oldest megalonychid, Deseadognathus, higher on the tree probably reflects the incompleteness of Deseadognathus, and the unresolved trichotomy of Proschismotherium, Mesopotamocnus, and Australonyx probably reflects the small number of characters in the data set. Despite these limitations, there is a general agreement between our and previous analyses on the broader relationships within the Megalonychidae. The results, therefore, do have heuristic value since we have been able to include genera that have not been included in previous analyses. Given the limited number of taxa represented by mandibles complete enough to obtain a reasonable number of characters, our goal was not to produce a comprehensive taxonomic revision of the family Megalonychidae, but rather to explore at a more basic level the possible relationships of the North and Central American megalonychids to each other and contemporaneous South American genera. Of special interest of course is where Zacatzontli n. gen. fits in these relationships in order to set the stage for future research. Of interest here is whether there was a single lineage of megalonychid sloths that dispersed into Central and North America and subsequently radiated or whether the diversity of megalonychids in Central and North America is the result of multiple distinct lineages of megalonychids dispersing north at different stages of the GABI. Zacatzontli n. gen. is currently known from a single locality dated 
as $\mathrm{Hh} 3$, so occurs later than the earliest well-dated record of Pliometanastes from the Siphon Canal locality in California at $8.19 \pm .16 \mathrm{Ma}$ (Hirschfeld, 1981), which at the moment suggests a separate dispersal. The spout morphology of Zacatzontli $\mathrm{n}$. gen. would appear to make it a better potential ancestor to Megalonyx than Pliometanastes, which has the more primitive elongated spout, but based on this single record it occurs after the earliest records of Megalonyx, which is also present in other similar age sites in Mexico. A second dispersal event of sloths in the later Hemphillian is also suggested by Thinobadistes, which also first occurs in the Hh3 (McDonald and Naples, 2008).

In our analysis we recovered two major clades within the megalonychids. The North American and Caribbean genera form one group, possibly reflecting their earlier dispersal and possibly a common shared ancestry, and the South American genera, possibly indicating subsequent evolution and diversification after the dispersal that founded the North AmericanCaribbean clade. The grouping of Zacatzontli $\mathrm{n}$. gen. from the Hemphillian of Mexico with the South American clade rather than with the North American-Caribbean clade suggests that these two major groups of megalonychid sloths had already diverged at this time.

\section{Paleobiogeography}

Webb's (2006) review of the GABI noted that the terrestrial fossil record for mammals in Central and North America unequivocally supports the presence of a significant water barrier between North and South America until 4-3 Myr. Besides the mammals, evidence for this barrier is also provided by the birds, especially the ecological specialist tropical forest birds (Weir et al., 2009; Smith and Klicka, 2010). The age of Zacatzontli tecolotlanensis $n$. gen. n. sp. suggests that it, like the sloths that dispersed into North America earlier in the Hemphillian, most likely crossed a water barrier in order to enter North America.

McDonald (2005) noted that of all the mammalian lineages of South American origin that entered North America during the Great American Biotic Interchange (GABI), the sloths were the most successful in terms of taxonomic diversity. The recognition of this new genus and species from the Hemphillian of Mexico increases our knowledge of that overall diversity during the earliest stages of the Great American Biotic Interchange. The discovery of this new sloth also requires a reexamination of McDonald's (2005) observation that at any one time there was only one representative of each of the major groups of sloths (megalonychid, nothrothere, megathere, and mylodont) present in North America at each stage of the GABI. This observation was biased by the very robust fossil record of xenarthrans from the temperate part of North America, primarily the United States and northern Mexico, which is in marked contrast to the smaller number of late Cenozoic localities and studies of the fauna from the tropical portion of southern Mexico and Central America. At least for the megalonychidae, we now have more than one representative of the family in the tropical portions of North America.

In addition to Meizonyx salvadorensis Webb and Perrigo, 1985 from the middle Pleistocene of El Salvador (Webb and Perrigo, 1985), the recognition of a second genus of megalonychid sloth, Zacatzontli n. gen., clearly demonstrates that the taxonomic diversity of fossil xenarthrans (and very likely other groups of South American origin as well) in the tropical portions of North and Central America is much greater than previously thought. This should not be unexpected given that the greatest taxonomic diversity of extant xenarthrans outside of South America today is in Central America and southern Mexico (i.e., the tropics), and includes all three genera of anteaters (Myrmecophaga tridactyla Linnaeus, 1758; Tamandua mexicana Saussure, 1860; and Cyclopes didactylus Linnaeus, 1758), two armadillos (Cabassous centralis Miller, 1899; and Dasypus novemcinctus Linnaeus, 1758; the only xenarthran taxon with a range that extends into the United States), and both genera of extant sloths, each represented by a single species (Bradypus variegatus Schinz, 1825 and Choloepus hoffmanni Peters, 1858), the "camp followers" of McDonald (2005).

Webb (2006) noted that while geographically southern Mexico and Central America are geologically tied to North America, having been widely and deeply separated from northern South America by the Bolivar Trough, today fauna and flora of this region are more similar to Neotropical South America - his Central American Paradox. As described by Webb (2006), Central America was conquered by the tropical fauna of South America, which is clearly indicated by the diversity of xenarthrans in this region. Because the majority of these taxa are restricted to tropical rainforest habitat, the northernmost limit for their distribution is at about the same latitude $\left( \pm 16^{\circ} \mathrm{N}\right)$ (Fig. 7). As discussed by McDonald (2005), the variety of habitats in Central and North America acted as "nested sieves" that restricted the northern dispersal of xenarthrans, and it is clear that the majority of taxa dispersing out of South America were adapted to a tropical habitat and hence restricted to how far north their range could extend. While the sloths (Pliometanastes, Megalonyx, Thinobadistes, Glossotherium/Paramylodon, Nothrotheriops, and Eremotherium) and the cingulates (Glyptotherium, Holmesina, Pachyarmatherium, Dasypus bellus Simpson, 1929, and to a lesser extent Pampatherium) extended their ranges into more northern temperate environments for geologically extended periods of time, it is becoming clear that there exists at least as great and possibly greater amount of currently undocumented xenarthran diversity in the tropical part of North America, which is only now being discovered.

Fluctuating climatic conditions through the Pliocene and Pleistocene did permit short-term northerly range expansions of some of the tropical taxa, such as the giant anteater, Myrmecophaga tridactyla, in the Middle Pleistocene (Irvingtonian) El Golfo fauna at $31.5^{\circ} \mathrm{N}$ (Shaw and McDonald, 1987), or even temperate taxa such as Megalonyx expanding its range as far north as the Yukon during the Sangamonian interglacial (McDonald et al., 2000).

Today, the Neotropics support an extremely large diversity of living mammals with $\sim 1500$ recognized species currently known, representing $\sim 30 \%$ of the total world mammal diversity. This biodiversity includes numerous endemic groups such as marsupials, xenarthrans (sloths, armadillos, and anteaters), caviomorph rodents, platyrrhine monkeys, and phyllostomid bats (Patterson and Costa, 2012). The existence of the variety of biomes present in the Neotropics (lowland rainforest, savannas, mountain forest, scrublands, and deserts) provides a partitioned 

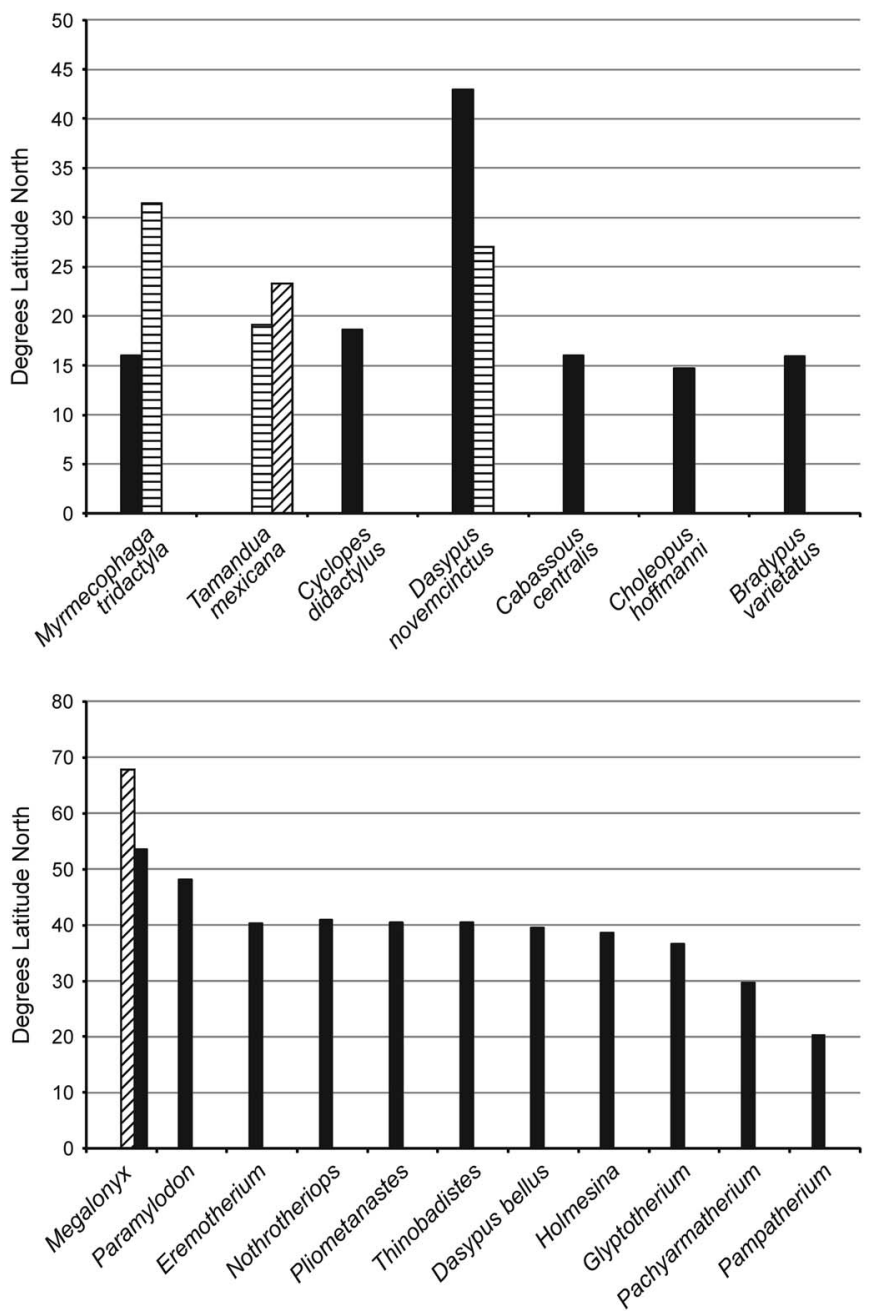

Figure 7. Comparison of maximum latitude of extant and fossil North American xenarthrans: (1) extant taxa, (2) extinct taxa. The striped bar for Myrmecophaga is the Irvingtonian range extension, the two bars for Tamandua show the differences on the Pacific and Gulf coasts, the two bars for Dasypus show the differences on the Pacific and Gulf coasts, and the striped bar for Megalonyx shows its Sangamonian range extension.

environment that enhances the overall species richness (Tews et al., 2004) along with the latitudinal gradient diversity (Jablonski et al., 2013).

Croft (2007) used the Simpson Index of faunal similarity to compare the middle Miocene Quebrada Honda Fauna from midlatitudes in Bolivia with the slightly older high-latitude fauna of Collón-Curá Argentina and noted that it was more similar to the older fauna than to the contemporaneous low-latitude fauna of La Venta in Colombia. He suggested isolating mechanisms existed between the low and middle latitudes during the early and/or middle Miocene. Carrillo et al. (2015), using dissimilarity analysis, showed that distinct tropical and temperate faunal assemblages existed in South America during the middle Miocene (Colloncuran-Laventan [ $\approx$ Langhian-Serravallian]) and late Miocene (Huayquerian-Montehermosan [ $\approx$ TortonianPiacenzian]). Their analysis of first appearances of taxa in the faunas examined showed that across time and latitude the faunistic movements related to GABI began during the late Miocene ( 10 Ma) with the oldest records found at higher latitudes. The number of FAD remained relatively low until 4-5 Myr when FAD starts to increase, peaking during the Pleistocene. They concluded that the study of paleodiversity patterns and paleobiogeography in the Americas is currently biased by the samples available (Carrillo et al., 2015).

Extrapolating from the possibility that there may exist a diverse number of currently unknown extinct sloth and other xenarthran taxa in the tropical portions of South America brings us full circle to the issue that many of the North American sloth taxa, such as Pliometanastes, Zacatzontli n. gen., and Thinobadistes, are not present in South America from similaraged faunas, or at least are not known from the well-documented similar-aged faunas of Argentina and the more temperate parts of South America.

Past studies have focused on the dispersal of taxa between North and South America in both directions following the formation of the land bridge by $\sim 3 \mathrm{Ma}$, as correlated with the expansion of savannas and grasslands in the Neotropics during glacial periods (Webb, 1991, 2006; Leigh et al., 2014). It appears that North American taxa seem to have been more successful utilizing more temperate biomes, whereas, in contrast, the South American taxa dominated in the tropics (Webb, 1991, 2006; Leigh et al., 2014). Therefore, attempting to derive the North American sloth taxa from taxa from the temperate part of South America should be reconsidered. Rather, it may be that at least some of the North American sloth taxa are instead derived from an ancestral stock that lived in the northern, and thus tropical, part of South America, which is an area that is greatly underrepresented by faunas in general as well as those that date to the beginning of the GABI. Gaudin and Croft (2015) attributed the rarity of early xenarthran remains not only to the general scarcity of fossil localities from tropical latitudes in South America, but also to low population densities associated with myrmecophagy and the lack of durable, enamelcovered teeth, which have been the basis for many of the described mammalian taxa from this region. The sediments in many of the known sites in tropical South America are marinefluvial in origin, and therefore represent significantly different environments than inland sites in the temperate latitudes (personal communication, D. Croft, 2017). The large number of early records of sloths in Hemphillian faunas in North America is an artifact of more fieldwork in this region, which is a mirror image of what is seen in temperate South America. With an increase in the recovery of sites in both tropical Central America (Laurito and Valerio, 2012) and South America (Rincon et al., 2016), it may be just a matter of time before Zacatzontli n. gen. and some of the other "endemic" North American sloth taxa are found in the tropical part of South America and a fuller understanding of xenarthran diversity and the participation of this group during the early stages of the GABI is possible.

\section{Conclusions}

The discovery of a new genus and species of megalonychid sloth, Zacatzontli tecolotlanensis, from the late Hemphillian of Jalisco, Mexico increases the diversity of taxa of South American origin that participated in the GABI. Zacatzontli $\mathrm{n}$. gen. in Mexico and another megalonychid sloth, Meizonyx, in El Salvador clearly show there is a greater diversity of taxa of South American origin in the northern Neotropics than had been 
previously suspected. This reflects the general paucity of Cenozoic fossil sites from the tropical lower latitudes in North America and that the majority of our knowledge of the diversity of taxa that participated in the GABI and the timing of their dispersal into North America has been based on faunas from higher latitudes. The presence of these sloths raises interesting questions in terms of the evolutionary history of the megalonychid sloths and whether their appearance in North America reflects multiple separate dispersal events or a smaller number of dispersals with the subsequent evolution of these taxa occurring in the tropical portions of North America. The presence of these taxa only in North America and their absence in South America suggest this may be the case, but alternatively could simply reflect that, as in North America, there are fewer sites from the late Cenozoic in the tropical parts of northern South America. These questions cannot be resolved until additional fieldwork in the adjoining tropical regions of South and North America provides us with a more robust fossil record.

\section{Acknowledgments}

Our thanks to the Centro de Geociencias of the Universidad Nacional Autónoma de México for the support and logistics to carry out the fieldwork and preparation of the fossil material. These were possible with the economic support of the project PAPIIT IN102817. We thank W.E. Miller of Brigham Young University for his participation during the research on the sedimentary basins of central Mexico, B. Kowallis from BYU for description of the geology and stratigraphy and radiometric ages of the Tecolotlán Basin. We thank J. Silva Corona for the figures and photographs in this work, $\mathrm{H}$. Troncoso for the preparation of the fossils collected, C. Luis Espinosa for his criticism of part of the manuscript, and C. Ortega (LA-ICPMS), Centro de Geociencias for the second analysis of ash. The Center for Field Research, and especially Earth Watch volunteers, are thanked for their support of the Fossils of the Sierra Madre project, and their invaluable help collecting fossils during this project. We thank P. Holroyd, UCMP, for providing pictures of the Pliometanastes from the Siphon Canal Locality and L. Fowler for providing the measurements of this specimen. S. Bargo, D. Brandoni, and S. Hirschfeld generously provided images of specimens from their publications. We thank our reviewers, D. Croft and G. DeIuliis, for their comments, which improved the quality of the paper.

\section{References}

Ameghino, F., 1885, Nuevos restos de mamíferos fósiles Oligocenos recogidos por el Profesor Pedro Scalabrini y pertenecientes al Museo Provincial de la ciudad de Paraná: Boletín de la Academia Nacional de Ciencias de Córdoba, v. 8, p. 5-207.

Ameghino, F., 1887, Enumeracion sistematica de las especies de mamiferos fosiles coleccionados por Carlos Ameghino en los terrenos eocenos de la Patagonia: Boletín del Museo de La Plata, v. 1, p. 1-26.

Bargo, M.S, Toledo, N., and Vizcaíno., S.F., 2012. Paleobiology of the Santacrucian sloths and anteaters (Xenarthra, Pilosa), in Vizcaíno, S.A., Kay, R.F., and Bargo, M.S., eds., Early Miocene Paleobiology in Patagonia: Cambridge, Cambridge University Press, p. 216-242.

Brandoni, D., 2010, On the systematics of Ortotherium Ameghino (Xenarthra, Tardigrada Megalonychidae) from the 'Conglomerado Osíferó' (Late Miocene) of Argentina: Journal of Vertebrate Paleontology, v. 30, p. 975-980.

Brandoni, D., 2014, A new genus of Megalonychidae (Mammalia, Xenarthra) from the late Miocene of Argentina: Revista Brasileira de Paleontologia, v. 17, p. $33-42$.
Brown, B., 1912, Brachyostracon, a new genus of glyptodonts from Mexico: American Museum of Natural History Bulletin, v. 31, p. 167-177.

Carlini, A.A., and Scillato-Yané, G.J., 2004, The oldest Megalonychidae (Xenarthra: Tardigrada); phylogenetic relationships and an emended diagnosis of the family: Neues Jahrbuch für Geologie und Paläontologie Abhandlungen, v. 233, p. 423-443.

Carranza, O., and Miller, W.E., 1980, The earliest capybara record in North America. Geological Society of America Abstracts with Programs, v. 12 , p. 399.

Carranza-Castañeda, O., 1991, Vertebrados Fósiles del Terciario del Estado Hidalgo, in Rubinovish-Kogan, R., and Carreño, A.L., eds., Convencion sobre la Evolucion Geologica de Mexico y I Congreso Mexicano de Mineralogia, Memoria: Universidad Nacional Autonoma de Mexico, Intituto de Geologia; Universidad Autonoma de Hidalgo, Instituto de Investigaciones de Ciencias de la Tierra; and Sociedad Mexicana de Mineralogia; Secretaria de Educacion Publica, p. 23.

Carranza-Castañeda, O., 2016, Roedores caviomorfos (Rodentia Hydrochoeridae) del Blancano temprano tardío-Irvingtoniano de los estados de Guanajuato, Jalisco y Sonora, México: relación con Phugatherium dichroplax: Revista Mexicana de Ciencias Geológicas, v. 33, p. 297-315.

Carranza-Castañeda, O., and Miller, W.E., 1988, Roedores caviomorfos de la Mesa Central de México, Blancano temprano (Plioceno tardío) de la fauna local Rancho Viejo, Guanajuato, México: Universidad Nacional Autónoma de México, Instituto de Geología, Revista, v. 7, p. 182-199.

Carranza-Castañeda, O., and Miller, W.E., 2004, Late Tertiary terrestrial mammals from Central Mexico and their relationship to South American immigrants: Revista Brasileira de Paleontologia, v. 7, p. 249-261.

Carranza-Castañeda, O., Aranda-Gómez, J.J., Wang, X., and Iriondo, A., 2013 The early-late Hemphillian (Hh2) faunal assemblage from Juchipila Basin, State of Zacatecas, Mexico, and its biochronological correlation with other Hemphillian faunas in Central Mexico: Natural History Museum of Los Angeles County, Contributions in Science, v. 521, p. 13-49.

Carrillo, J.D., Forasiepi, A., Jaramillo, C., and Sánchez-Villagra, M.R., 2015 , Neotropical mammal diversity and the Great American Biotic Interchange: spatial and temporal variation in South America's fossil record: Frontiers in Genetics, v. 5, p. 1-11.

Cartelle, C., De Iuliis, G., and Pujos, F., 2008, A new species of Megalonychidae (Mammalia, Xenarthra) from the Quaternary of Poço Azul (Bahia, Brazil): Comptes Rendus Palevol, v. 7, p. 335-346.

Cook, H.J., 1922, A Pliocene fauna from Yuma County, Colorado, with notes on the closely related Snake Creek beds from Nebraska: Proceedings of the Colorado Museum of Natural History, v. 4, p. 3-30.

Cope, E.D., 1878, Descriptions of new extinct vertebrata from the Upper Tertiary and Dakota Formations: Bulletin of the United States Geological and Geographical Survey of the Territories, v. 4, p. 379-396.

Cope, E.D., 1889, The Edentata of North America: American Naturalist, v. 23, p. $657-664$.

Cope, E.D., 1892, A contribution to a knowledge of the fauna of the Blanco beds of Texas: Academy of Natural Sciences Proceedings, v. 44, p. 226-229.

Cope, E.D., 1893, A preliminary report on the vertebrate paleontology of the Llano Estacado: Geological Survey of Texas, Annual Report, $4^{\text {th }}$, p. $1-36$.

Croft, D.A., 2007, The middle Miocene (Laventan) Quebrada Honda fauna, southern Bolivia, and a description of its notoungulates: Palaeontology, v. 5 , p. $277-303$.

De Iuliis, G., Pujos, F., and Cartelle, C., 2009, A new ground sloth (Mammalia: Xenarthra) from the Quaternary of Brazil: Comptes Rendus Palevol, v. 8, p. $705-715$.

De Iuliis, G., Cartelle, C., and Pujos, F., 2016, New Pleistocene remains of megalonychid ground sloths (Xenarthra, Pilosa) from the intertropical Brazilian region: Journal of Paleontology, v. 90, p. 578-587.

Flower, W.H., 1883, On the arrangement of the orders and families of existing Mammalia: Proceedings of the Zoological Society of London, v. 1883, p. $178-186$.

Flynn, J.J., Kowallis, B.J., Nuñez, C., Carranza-Castañeda, O., Miller, W.E., Swisher, C.C., and Lindsay, E., 2005, Geochronology of HemphillianBlancan aged strata, Guanajuato, Mexico, and implications of the Great American Biotic Interchange: Journal of Geology, v. 113, p. 287-307.

Furlong, E.L., 1941, A new Pliocene antelope from Mexico with remarks on some known antilocaprids: Publication of the Carnegie Institute of Washington, v. 530, p. 25-33.

Gaudin, T.J., 1995, The ear region of edentates and the phylogeny of the Tardigrada (Mammalia, Xenarthra): Journal of Vertebrate Paleontology, v. 15 , p. $672-705$.

Gaudin, T.J., 2004, Phylogenetic relationships among sloths (Mammalia, Xenarthra, Tardigrada): the craniodental evidence: Zoological Journal of the Linnaean Society, v. 140, p. 255-305.

Gaudin, T.J., and Croft, D.A., 2015, Paleogene Xenarthra and the evolution of South American mammals: Journal of Mammalogy, v. 96, p. 622-634. 
Gervais, P., 1855, Recherches sur les mammiféres fossiles de l'Amérique méridionale: Paris, P. Bertrand, $62 \mathrm{p}$.

Gillette, D.D., Carranza-Castañeda, O., White, R.S., Jr., Morgan, G.S., Thrasher, L.C., McCord, R., and McCullough, G., 2016, Ontogeny and sexual dimorphism of Glyptotherium texanum (Xenarthra-Cingulata) from the Pliocene and Pleistocene (Blancan-Irvingtonian NALMA) of Arizona, New Mexico and Mexico: Journal of Mammal Evolution, v. 23, p. 133-154.

Goloboff, P., Farris, J., and Nixon, K., 2008, T.N.T. A free program for phylogenetic analysis: Cladistics, v. 24, p. 774-786.

Gómez-Tuena, A., Orozco-Esquivel, T., and Ferrari, L., 2007, Igneous petrogenesis of the Trans-Mexican Volcanic Belt, in Alaniz-Álvarez, S.A., and Nieto-Samaniego, A.F., eds., Geology of México: Celebrating the Centenary of the Geological Society of México: Geological Society of America Special Paper 422, p. 129-181. doi: 10.1130/2007.2422(05)

Hirschfeld, S.E., 1981, Pliometanastes protistus (Edentata, Megalonychidae) from Knight's Ferry, California with discussion of Early Hemphillian megalonychids: PaleoBios, v. 36, p. 1-16.

Hirschfeld, S.E., and Webb, S.D., 1968, Plio-Pleistocene megalonychid sloths of North America: Bulletin of the Florida State Museum, Biological Sciences, v. 12 , p. $213-296$

Hooijer, D.A., 1962, A fossil ground sloth from Curaçao, Netherlands Antilles: Proceedings of the Koninklijke Nederlandse Akademie van Wetenschappen Amsterdam, series B, v. 65, p. 46-60.

Jablonski, D., Belanger, C.L., Berke, S.K., Huang, S., Krug, A.Z., Roy, A., Tomasovych, A., and Valentine, J.W., 2013, Out of the tropics, but how? Fossils, bridge species, and thermal ranges in the dynamics of the marine latitudinal diversity gradient: Proceedings of the National Academy of Sciences, v. 110, p. 10487-10494.

Kowallis, J.B., Carranza-Castañeda, O., Miller, W.E., Toblen, K., and Christiansen, E., 1998, Extension, sedimentation and volcanism in the Tecolotlán- Juchitlán graben, Jalisco, Mexico: Geological Society of America, Annual Meeting, Abstracts with Programs, v. 30, p. 171.

Kowallis, B., Miller, W.E., Carranza-Castañeda, O., Christiansen, E.H., Swisher, C.C., III, Ross, K.T., Deino, A.L., and Tingey, D.G., 2003, The Tecolotlán Graben: a record of sedimentation and volcanism from Cretaceous and Tertiary volcanic arcs, Geological Society of America, Annual Meeting: Puerto Vallarta Mexico, Abstracts with Programs, v. 35, p. 77.

Kowallis, B.J., Christiansen, E.H., Carranza-Castañeda, O., Miller, W.E., Ross, K.T., and Tingey, D.G., 2017, The Geology of the Tecolotlan Graben, Jalisco, Mexico: Geological Society of America Digital Map and Chart, v. 22, 37 p. doi:10.1130/2017.DMCH022.TXT

Kraglievich, L., 1923, Descripción de dos cráneos y otros restos del género Pliomorphus Ameghino procedentes de la formación Entrerriana de las barrancas del Río Paraná: Anales del Museo Nacional de Historia Natural de Buenos Aires, v. 33, p. 1-56.

Lance, J.F., 1950, Paleontología y estratigrafía del Plioceno de Yepómera, estado de Chihuahua; 1a Parte, Équidos, except Neohipparion: Universidad Nacional Autonoma de México, Instituto de Geología, Boletín 54, 81 p.

Laurito, C.A., and Valerio, A.L., 2012, Primer registro fósil de Pliometanastes sp. (Mammalia, Xenarthra, Megalonychidae) para el Mioceno Superior de Costa Rica, América Central. Una nueva pista en la comprensión del Pre-GABI: Revista Geológica de América Central, v. 47, p. 95-108.

Leigh, E.G., O'Dea, A., and Vermeij, G.J., 2014, Historical biogeography of the Isthmus of Panama: Biological Reviews, v. 89, p. 148-172.

Lindsay, E., Mou, Y., Downs, W., Pederson, J., Kelly, T.S., Henry, C., and Trexler, J., 2002, Recognition of the Hemphillian/Blancan boundary in Nevada: Journal of Vertebrate Paleontology, v. 22, p. 429-442.

Linnaeus, C., 1758, Systema Naturae per Regna Tria Naturae: Secundum Classes, Ordines, Genera, Species, cum Characteribus, Differentiis, Synonymis, Locis, $10^{\text {th }}$ ed.: Stockholm, Laurentius Salvius, 824 p.

Matthew, W.D., 1924, Third contribution to the Snake Creek Fauna: Bulletin of the American Museum of Natural History, v. 50, p. 59-210.

Matthew, W.D., and Cook, H.J., 1909, A Pliocene fauna from western Nebraska: Bulletin of the American Museum of Natural History, v. 26, p. 361-414.

Matthew, W.D., and Osborn, H.F., 1909, Faunal list of the Tertiary mammalia of the west: Bulletin of the United States Geological Survey, v. 361, p. 91-138.

Matthew, W.D., and Paula Couto, C. de, 1959, The Cuban edentates: Bulletin of the American Museum of Natural History 117, p. 1-56.

Mayo, N., 1980, Revisión de Neocnus major Arredondo, 1961 (Mammalia: Edentata del Pleistoceno de Cuba) con descripción de un cráneo y algunos huesos postcraneales: Estudios Geológicos, v. 36, p. 427-440.

McDonald, H.G., 1977, Description of the osteology of the extinct gravigrade edentate, Megalonyx, with observations on its ontogeny, phylogeny and functional anatomy [Masters thesis]: Gainesville, Florida, University of Florida, Gainesville, 328 p.

McDonald, H.G., 2005, Paleoecology of extinct Xenarthrans and the Great American Biotic Interchange: Bulletin of the Florida Museum of Natural History, v. 45, p. 313-333.
McDonald, H.G., and De Iuliis, G., 2008, Fossil history of sloths, in Vizcaíno, S.F., and Loughry, J., eds., The Biology of the Xenarthra: Gainesville, University of Florida Press, p. 39-55.

McDonald, H.G., and Naples, V.L., 2008, Xenarthra, in Janis, C.M., Gunnell, G.F., and Uhen, M.D., eds., Evolution of Tertiary Mammals of North America, Volume 2: Small Mammals, Xenarthrans, and Marine Mammals: Cambridge, Cambridge University Press, p. 147-160.

McDonald, H.G., Harington, C.R., and De Iuliis, G., 2000, The ground sloth, Megalonyx, from Pleistocene deposits of the Old Crow Basin, Yukon, Canada: Arctic, v. 53, p. 213-220.

McDonald, H.G., Rincón, A.D., and Gaudin, T.J., 2013, A new genus of megalonychid sloth (Mammalia, Xenarthra) from the Late Pleistocene (Lujanian) of Sierra de Perija, Zulia State, Venezuela: Journal of Vertebrate Paleontology, v. 33, p. 1226-1238.

Miller, G.S., Jr., 1899, Notes on the naked-tailed armadillos: Proceedings of the Biological Society of Washington, v. 13, p. 1-8.

Miller, W.E., and Carranza-Castaneda, O., 1998, Late Tertiary canids from central Mexico: Journal of Paleontology, v. 72, p. 546-556.

Miller, W.E., and Carranza-Castañeda, O., 1999, Early South American immigrants in central Mexico, and times of their appearances: Journal of Vertebrate Paleontology, v. 19, p. 64A.

Miller, W.E., and Carranza-Castañeda, O., 2001, Late Cenozoic mammals from the basins of central Mexico: Bollettino della Societa Paleontologica Italiana, v. 40, p. 235-242.

Montellano-Ballesteros, M., and Carranza-Castañeda, O., 1981, Edentados Pliocenicos de la region central de Mexico. Anais II Congresso LatinoAmericano Paleontologia, Porto Alegre:683-695.

Montellano-Ballesteros, M., and Carranza-Castañeda, O., 1986, Descripción de un milodóntido del Blancano temprano de la Mesa Central de México: Universidad Nacional Autónoma de Mexico, Instituto de Geología Revista, v. 6 , p. $193-203$.

Mooser, O., 1968, Fossil Equidae from the middle Pliocene of the Central Plateau of Mexico: Southwest Naturalist, v. 13, p. 1-12.

Naples, V.L., 1982, Cranial osteology and function in the tree sloths, Bradypus and Choloepus: American Museum Novitates, v. 2739, p. 1-41.

Naples, V.L., 1987, Reconstruction of cranial morphology and analysis of function in the Pleistocene ground sloth Nothrotheriops shastense (Mammalia, Megatheriidae): Contributions in Science, Natural History Museum of Los Angeles County, v. 389, p. 1-21.

Osborn, H.F., 1903, Glyptotherium texanum, a new glyptodont, from the Lower Pleistocene of Texas: Bulletin of the American Museum of Natural History, v. 19, p. 491-494.

Osborn, H.F., 1923, New subfamily, generic, and specific stages in the evolution of the Proboscidea: American Museum Novitates, v. 99, p. 1-4.

Paizanni-Herrera, F., Ramirez-Romo, J., Gamez-Ordaz, V., and Ávila-Lugo, F., 1999, Carta geológico-minera, Puerto Vallarta F13-11, Jalisco and Nayarit [Mexico]: Pachuca, Hidalgo, Servicio Geológico Mexicano, 1 sheet, scale $1: 250,000$.

Patterson, B., Segall, W., Turnbull, W.D., and Gaudin, T.J., 1992, The ear region in Xenarthrans (=Edentata: Mammalia) Part II. Pilosa (Sloths, Anteaters), palaeanodonts, and a miscellany: Fieldiana Geology, new series, v. 24, p. $1-79$.

Patterson, B.D., and Costa, L.P., 2012, Introduction to the history and geography of Neotropical mammals, in Patterson, B.D., and Costa, L.P., eds., Bones, Clones and Biomes. The History and Geography of Recent Neotropical Mammals: Chicago, London, The University of Chicago Press, p 1-5.

Paula Couto, C. de, 1967, Pleistocene edentates of the West Indies: American Museum Novitates, v. 2304, p. 1-55.

Peters, W., 1858, [Charakterist eines neuen zweizehigen FauIthiers.] Monatsberichte der Koniglichen Preuss: Akademie der Wissenschaften zu Berlin, v. 1858, p. 128

Rosas-Elguera, J., Ferrari, L., Garduño-Monroy, V.H., and Urrutia-Fucugauchi, J., 1996, Continental boundaries of the Jalisco block and their influence in the Pliocene-Quaternary kinematics of western Mexico: Geology, v. 24, p. $921-924$.

Rincón, A.D., Solórzano, A., Macsotay, O., McDonald, H.G., and NúñezFlores, M., 2016, A new Miocene vertebrate assemblage from the Río Yuca Formation (Venezuela) and the northernmost record of typical Miocene mammals of high latitude (Patagonian) affinities in South America: GeoBios, v. 49, p. 395-405.

Saussure, H. de, 1860, Note Sur Quelques Mammifères du Mexique: Revue et Magazín de Zoologie ser. 2, v. 12, p. 3-11.

Schinz, H.R., 1825, Das Thierreich eingetheilt nach dem Bau der Thiere als Grundlage ihrer Naturgeschichte und der vergleichenden Anatomie, v. 4: Stuttgart and Tübingen, Germany, J. G. Cotta, 793 p.

Scott, W.B., 1903-1904, Mammalia of the Santa Cruz Beds. Part 1: Edentata: Reports of the Princeton Expeditions to Patagonia, 1896-1899, v. 5, p. $1-364$. 
Sellards, E.H., 1916, Fossil vertebrates from Florida: a new Miocene fauna; new Pliocene species; the Pleistocene fauna: Florida State Geological Survey Annual Report 8, p. 79-119.

Shaw, C.A., and McDonald, H.G., 1987, First record of giant anteater (Xenarthra, Myrmecophagidae) in North America: Science, v. 236, p. 186-188.

Simpson, G.G., 1929, Pleistocene mammalian fauna of the Seminole Field, Pinellas County, Florida: American Museum of Natural History Bulletin, v. 56, p. 561-599.

Simpson, G.G., 1932, Some new or little-known mammals from the Colpodon beds of Patagonia: American Museum Novitates, v. 575, p. 1-12.

Smith, B.T, and Klicka, J., 2010, The profound influence of the Late Pliocene Panamanian uplift on the exchange, diversification, and distribution of New World birds: Ecogeography, v. 33, p. 333-342.

Tews, J., Brose, U., Grimm, V., Tielbörger, K., Wichmann, M.C., Schwager, M., and Jeltsch, F., 2004, Animal species diversity driven by habitat heterogeneity/diversity: the importance of keystone structures: Journal of Biogeography, v. 31, p. 79-92. DOI: 10.1046/j.0305-0270.2003.00994.x

Webb, S.D., 1965, The osteology of Camelops: Bulletin of the Los Angeles County Museum, Science, v. 1, p. 1-54.

Webb, S.D., 1989, Osteology and relationships of Thinobadistes segnis, the firs mylodont sloth in North America, in Redford, K.H., and Eisenberg, J.F., eds., Advances in Neotropical Mammalogy: Gainesville, Florida, Sandhill Crane Press, p. 469-532.
Webb, S.D., 1991, Ecogeography and the Great American Interchange: Paleobiology, v. 17, p. 266-280.

Webb, S.D., 2006, The Great American Biotic Interchange: patterns and processes 1. Annals of the Missouri Botanical Garden 93, p. 245-257.

Webb, S.D., and Perrigo, S., 1985, New megalonychid sloths from El Salvador, in Montgomery, G.G., ed., The Evolution and Ecology of Armadillos, Sloths and Vermilinguas: Washington, D.C., Smithsonian Institution Press, p. $113-120$.

Weir, J.T., Bermingham, E., and Schluter, D., 2009, The Great American Biotic Interchange in birds: Proceedings of the National Academy of Science, v. 106, p. 21737-21742.

White, J.L., and MacPhee, R.D.E., 2001, The sloths of the West Indies: a systematic and phylogenetic review, in Woods, C.A., and Sergile, F.E., eds., Biogeography of the West Indies: Patterns and Perspectives, second edition: Boca Raton, Florida, CRC Press, p. 201-235.

Woodburne, M.O., 2010, The Great American Biotic Interchange: dispersals, tectonics, climate, sea level and holding pens: Journal of Mammalian Evolution, v. 17, p. 245-264

Accepted 16 May 2017 